\title{
Demographics Differences on Media Social as Representation Awareness Volunteer Among Youth in Malaysia
}

Sharifah Nurnadia, Aziz Amin

To Link this Article: http://dx.doi.org/10.6007/IJARBSS/v10-i11/7778

DOI:10.6007/IJARBSS/v10-i11/7778

Received: 02 September 2020, Revised: 20 September 2020, Accepted: 11 October 2020

Published Online: 06 November 2020

In-Text Citation: (Nurnadia, \& Amin, 2020)

To Cite this Article: Nurnadia, S., \& Amin, A. (2020). Demographics Differences on Media Social as Representation Awareness Volunteer Among Youth in Malaysia. International Journal of Academic Research in Business and Social Sciences. 10(11), 26-36.

\section{Copyright: (c) 2020 The Author(s)}

Published by Human Resource Management Academic Research Society (www.hrmars.com)

This article is published under the Creative Commons Attribution (CC BY 4.0) license. Anyone may reproduce, distribute, translate and create derivative works of this article (for both commercial and non-commercial purposes), subject to full attribution to the original publication and authors. The full terms of this license may be seen at: http://creativecommons.org/licences/by/4.0/legalcode

\section{Vol. 10, No. 11, 2020, Pg. 26 - 36}




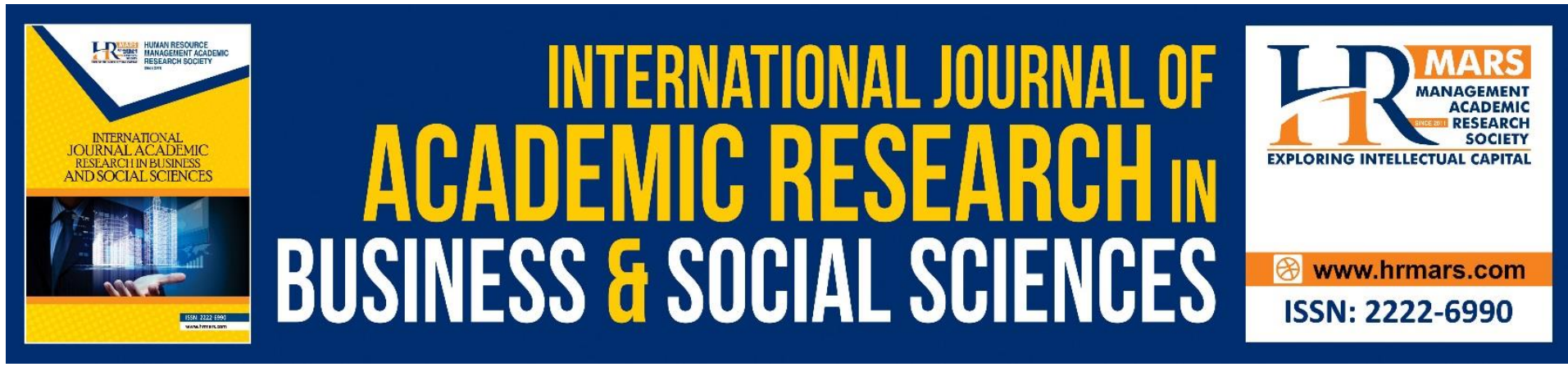

\title{
Demographics Differences on Media Social as Representation Awareness Volunteer Among Youth in Malaysia
}

\author{
Sharifah Nurnadia, Aziz Amin \\ Faculty of Applied Social Sciences, Universiti Sultan Zainal Abidin, Malaysia. \\ Email:wanazizmn@unisza.edu.my
}

\begin{abstract}
In this era of modernization, the media has played a role in the development of the country. This study aims to study the representation of social media as a tool for youth volunteerism in Malaysia. Youth mostly use social media and the extent to which social media can contribute and benefit to society. This study's objectives were to identify differences in the level of volunteer awareness by demographics: gender, education, occupation, race, and state among youth in Malaysia. Social media representation is separated into several aspects: religious activity, community and social service, culture, arts, and sports and education. This study involved 98 samples of youths aged 20 to 35, and quantitative research methods used through questionnaire distribution. Then, data collected were analyzed using SPSS (Statistical Package for Social Science) software. Researchers use frequency and descriptive analysis to examine social media representation and the level of volunteer awareness. The findings indicate a significant relationship between social media representation in religious activities, community and social services, culture, arts, sports, and education. The results show that the representation of social media through aspects of community and social service as well as culture, arts, and sports have an impact and influence on volunteer awareness. Social media representation has indeed played a role in the social awareness of volunteerism among youth.
\end{abstract}

Keywords: Demographic, Social Media, Volunteer Awareness, Youth

\section{Introduction}

To convey information, build perceptions and perceptions, and shape society's attitude, the mass media is an important tool or instrument as a mediator to send a specific message. The media's benefits convey information and play a role in shaping society's mindset (Falina, Mahmud, \& Mahbob, 2016). Falina et al. (2016) in their research, focused on the role of media as a tool of social awareness among people with disabilities. This shows that social media is a significant tool to contribute to Malaysian society.

Youths are the main group of social media users in this country (Ishak et al., 2016). Youth has its role and importance in efforts to develop society and the country. Superior personality strength will develop with the active involvement of youth in social activities and 
volunteerism. Even Wilson (2000) also agrees that the spirit of volunteerism is one of the core values that must exist among the younger generation because this group will determine the progress or backwardness of a country.

Batson, Ahmad, \& Tsang (2002); Wilson (2000) view that the spirit of volunteerism is also considered a core value that must exist for modern society, especially among the younger generation. However, volunteer awareness is closely related to the representation of social media inactivity and the program that has been published. Bahari (2010) noted that the potential and appropriateness of community work approaches and methods used or adapted by the government, youth movement, voluntary organizations, media, religious institutions, and local communities to help the community address social problems involving youth. Therefore, this study also emphasizes social media representation in education, sports and culture, religious activities, and community service.

Thus, the title of this study highlight in line with the statement of Shah, Suandi, Hamzah, \& Ismail (2015), that further research on the idea of youth involvement and the voluntary impact on volunteers, especially in Malaysia. Delgado (2002) also asserted that researchers should focus on the process and representation of social media to positive youth to understand youth's needs and wants, especially in producing the next generation of more excellent leaders. To ensure that social media is used optimally, various aspects need to be explored. Among them are genders, level of education, state, and race, which will dominate volunteerism among the youth. Besides, volunteer activities should be the view of every dimension.

The objective of the study is to;

- Examine the demographic differences in social media representation as a tool of volunteer awareness among youth in Malaysia.

\section{Literature Review}

Many scholarly reports state that individual involvement in volunteer activities is closed related to age and gender backgrounds. The involvement of male student groups in volunteer activities reflects the strength of value and social elements caused by a high desire to help society. At the same time, studies by Ribaric, Nimac, \& Nad (2013) show that female students focused on the activity's function. And most individuals involved in volunteer work are intended to help meet the community's basic needs in need.

Researchers strongly support the notion that the media are compelling and able to influence society and shape social change (Tiung, Idris, \& Idris, 2018). The media has been label as an agent of social change whose influence exceeds that of other voices. Although social media is overgrowing, there are still weaknesses in awareness to the community about current issues and humanitarian issues (Ishak et al., 2016).

Brennan, Barnett, \& Lesmeister (2007) concluded that youths involved in community development have the potential to solve problems and make decision-making skills as well as excel as a leader. It is empowering youth by engaging them in community activities that have many positive impacts.

Eight scopes of involvement of welfare volunteers under the Department of Social Welfare 
are guidance and counseling services, foster families, member and speech rehabilitation services, moral and academic education, sports, cultural and arts programs, religious programs, employee placement, and buddy volunteer system packages. Nadarajaw (2014) also emphasizes various types of volunteer activities that can help the community, including education, religious activities, environment, and community service. This causes researchers to use five dimensions of the study of social media representation as a tool of volunteer awareness among youth in Malaysia

\section{Methodology}

The study was applied in a cross-sectional survey using quantitative methods. A total of 98 samples of studies were selected from various youth backgrounds in Malaysia. This questionnaire uses five-scale feedback, starting from the lowest scale, namely strongly disagree, to the highest scale, strongly agreed (Zolkifeli \& Amin, 2018; Amin, Zolkifeli, \& Hassan, 2019; and Zolkifeli \& Amin, 2019). The questionnaire contains 41 items and five dimensions of volunteer activity. Data were analyzed using Statistical Package for Social Science (SPSS). The differences level of volunteer awareness between the genders was tested using the t-test method. While education, occupation, state, and race were tested using the ANOVA test method in SPSS.

\section{Results and Discussions}

The t-test analysis shows the tables of group statistics (table 1 ) and independent sample tests (table 2).

\begin{tabular}{|c|c|c|c|c|c|}
\hline \multicolumn{6}{|c|}{ Table 1: Group Statistics } \\
\hline Dimensions & Gender & $\mathrm{N}$ & Mean & $\begin{array}{c}\text { Std. } \\
\text { Deviation }\end{array}$ & $\begin{array}{l}\text { Std. } \\
\text { Error } \\
\text { Mean }\end{array}$ \\
\hline \multirow{2}{*}{$\begin{array}{l}\text { Religious } \\
\text { Activities }\end{array}$} & Male & 37 & 3.8417 & .58008 & .09536 \\
\hline & Female & 61 & 3.8454 & .46606 & .05967 \\
\hline \multirow{2}{*}{$\begin{array}{l}\text { Community and } \\
\text { Social Services }\end{array}$} & Male & 37 & 3.8456 & .57870 & .09514 \\
\hline & Female & 61 & 3.9696 & .47817 & .06122 \\
\hline \multirow{2}{*}{$\begin{array}{l}\text { Culture, Arts, } \\
\text { and Sports }\end{array}$} & Male & 37 & 3.7143 & .60796 & .09995 \\
\hline & Female & 61 & 3.7119 & .65074 & .08332 \\
\hline \multirow[t]{2}{*}{ Education } & Male & 37 & 3.7683 & .64184 & .10552 \\
\hline & Female & 61 & 3.7986 & .63266 & .08100 \\
\hline \multirow{2}{*}{$\begin{array}{l}\text { Volunteer } \\
\text { Awareness }\end{array}$} & Male & 37 & 4.0695 & .58575 & .09630 \\
\hline & Female & 61 & 4.1405 & .42176 & .05400 \\
\hline
\end{tabular}




\begin{tabular}{|c|c|c|c|c|c|c|}
\hline \multicolumn{7}{|c|}{ Table 2: Independent Samples Test } \\
\hline & & \multicolumn{2}{|c|}{$\begin{array}{l}\text { Levene's Test } \\
\text { for Equality of } \\
\text { Variances }\end{array}$} & \multicolumn{3}{|c|}{ t-test for Equality of Means } \\
\hline & & $\mathrm{F}$ & Sig. & $\mathrm{t}$ & df & $\begin{array}{l}\text { Sig. (2- } \\
\text { tailed) }\end{array}$ \\
\hline \multirow[t]{2}{*}{$\begin{array}{l}\text { Religious } \\
\text { Activities }\end{array}$} & $\begin{array}{l}\text { Equal variances } \\
\text { assumed }\end{array}$ & 2.753 & .100 & -.035 & 96 & .972 \\
\hline & $\begin{array}{l}\text { Equal variances not } \\
\text { assumed }\end{array}$ & & & -.033 & $\begin{array}{r}63.83 \\
8\end{array}$ & .974 \\
\hline \multirow{2}{*}{$\begin{array}{l}\text { Community } \\
\text { and Social } \\
\text { Services }\end{array}$} & $\begin{array}{l}\text { Equal variances } \\
\text { assumed }\end{array}$ & 3.074 & .083 & -.699 & 96 & .254 \\
\hline & $\begin{array}{l}\text { Equal variances not } \\
\text { assumed }\end{array}$ & & & -.684 & $\begin{array}{r}65.27 \\
4 \\
\end{array}$ & .277 \\
\hline \multirow{2}{*}{$\begin{array}{l}\text { Culture, } \\
\text { Arts, and } \\
\text { Sports }\end{array}$} & $\begin{array}{l}\text { Equal variances } \\
\text { assumed }\end{array}$ & .038 & .847 & .392 & 96 & .986 \\
\hline & $\begin{array}{l}\text { Equal variances not } \\
\text { assumed }\end{array}$ & & & .408 & $\begin{array}{r}80.18 \\
6 \\
\end{array}$ & .986 \\
\hline \multirow[t]{2}{*}{ Education } & $\begin{array}{l}\text { Equal variances } \\
\text { assumed }\end{array}$ & .094 & .760 & .191 & 96 & .820 \\
\hline & $\begin{array}{l}\text { Equal variances not } \\
\text { assumed }\end{array}$ & & & .195 & $\begin{array}{r}75.25 \\
3 \\
\end{array}$ & .821 \\
\hline \multirow[t]{2}{*}{$\begin{array}{l}\text { Volunteer } \\
\text { Awareness }\end{array}$} & $\begin{array}{l}\text { Equal variances } \\
\text { assumed }\end{array}$ & 3.744 & .056 & -.696 & 96 & .488 \\
\hline & $\begin{array}{l}\text { Equal variances not } \\
\text { assumed }\end{array}$ & & & -.643 & $\begin{array}{r}58.71 \\
8\end{array}$ & .523 \\
\hline
\end{tabular}

Through the t test, overall, there was no significant difference in social media representation and volunteer awareness among genders between males and females. Based on the table above, the study findings revealed an overall volunteer awareness factor $(\mathrm{t}=-0.696$, sig. $=$ 0.488 ). In terms of education ( $t=-0.228$, sig. $=0.820)$, culture, arts and sports $(t=0.018$, sig. $=0.986)$, community and social services $(t=-1.148$, sig. $=0.254)$ and religious activities $(t=-$ 0.035 , sig. $=0.972)$, where the value of sig. $p>0.05$.

All dimensions show that there is no significant difference in volunteer awareness between males and females. The result indicates that the males' mean value is higher than females for three volunteer awareness dimensions based on the mean value. Based on the above results, this study found no difference in volunteer awareness between males and females youth in Malaysia. It is essential so that both genders can live a balanced life.

Based on the ANOVA analysis, findings show that the tables of one way ANOVA volunteer awareness by the level of education (Table 3 ). 
INTERNATIONAL JOURNAL OF ACADEMIC RESEARCH IN BUSINESS AND SOCIAL SCIENCES Vol. 10, No. 11, 2020, E-ISSN: 2222-6990 @ 2020 HRMARS

\begin{tabular}{|c|c|c|c|c|c|c|}
\hline \multicolumn{7}{|c|}{ Table 3: One Way ANOVA Volunteer Awareness by Level of Education } \\
\hline & & $\begin{array}{l}\text { Sum of } \\
\text { Squares }\end{array}$ & df & $\begin{array}{l}\text { Mean } \\
\text { Square }\end{array}$ & $\mathrm{F}$ & Sig. \\
\hline \multirow[t]{3}{*}{$\begin{array}{l}\text { Religious } \\
\text { Activities }\end{array}$} & $\begin{array}{l}\text { Between } \\
\text { Groups }\end{array}$ & 1.036 & 4 & .259 & .999 & .412 \\
\hline & Within Groups & 24.110 & 93 & .259 & & \\
\hline & Total & 25.146 & 97 & & & \\
\hline \multirow{3}{*}{$\begin{array}{l}\text { Community } \\
\text { and Social } \\
\text { Services }\end{array}$} & $\begin{array}{l}\text { Between } \\
\text { Groups }\end{array}$ & .670 & 4 & .168 & .612 & .655 \\
\hline & Within Groups & 25.459 & 93 & .274 & & \\
\hline & Total & 26.129 & 97 & & & \\
\hline \multirow{3}{*}{$\begin{array}{l}\text { Culture, } \\
\text { Arts, and } \\
\text { Sports }\end{array}$} & $\begin{array}{l}\text { Between } \\
\text { Groups }\end{array}$ & 4.525 & 4 & 1.131 & 3.077 & .020 \\
\hline & Within Groups & 34.189 & 93 & .368 & & \\
\hline & Total & 38.714 & 97 & & & \\
\hline \multirow[t]{3}{*}{ Education } & $\begin{array}{l}\text { Between } \\
\text { Groups }\end{array}$ & .451 & 4 & .113 & .273 & .895 \\
\hline & Within Groups & 38.416 & 93 & .413 & & \\
\hline & Total & 38.867 & 97 & & & \\
\hline \multirow[t]{3}{*}{$\begin{array}{l}\text { Volunteer } \\
\text { Awareness }\end{array}$} & $\begin{array}{l}\text { Between } \\
\text { Groups }\end{array}$ & 2.571 & 4 & .643 & 2.907 & .026 \\
\hline & Within Groups & 20.570 & 93 & .221 & & \\
\hline & Total & 23.141 & 97 & & & \\
\hline
\end{tabular}

Through the ANOVA test, overall, there was no significant difference in volunteer awareness according to the level of education category. Based on the table above, the study findings revealed an overall volunteer awareness factor $(F=2.907$, sig. $=0.026)$. In terms of education $(F=0.273$, sig. $=0.895)$ culture, arts and sports $(F=3.077$, sig. $=0.020)$, community and social services $(F=0.612$, sig. $=0.655)$ and religious activities $(F=0.999$, sig. $=0.412)$, where the value of sig. $p>0.05$.

All dimensions show that there is no significant difference in volunteer awareness between the level of education. The total variance between the culture, arts, and sports groups exceeded the group's total variance. There is a difference in scores for the group's dimension, and there is no difference in the dimension of education, community involvement, and religious activities.

Based on the above results, this study found no difference between education level in terms of volunteer awareness. It is important so that all education levels are aware of volunteerism's importance in jointly developing the country. 
Based on the ANOVA analysis, findings show that the tables of one way ANOVA by occupation (Table 4).

\begin{tabular}{|c|c|c|c|c|c|c|}
\hline & & $\begin{array}{l}\text { Sum of } \\
\text { Squares }\end{array}$ & df & $\begin{array}{l}\text { Mean } \\
\text { Square }\end{array}$ & $\mathrm{F}$ & Sig. \\
\hline \multirow{3}{*}{$\begin{array}{l}\text { Religious } \\
\text { Activities }\end{array}$} & Between Groups & 2.246 & 4 & .561 & 2.280 & .067 \\
\hline & Within Groups & 22.901 & 93 & .246 & & \\
\hline & Total & 25.146 & 97 & & & \\
\hline \multirow{3}{*}{$\begin{array}{l}\text { Community } \\
\text { and Social } \\
\text { Services }\end{array}$} & Between Groups & .432 & 4 & .108 & .391 & .814 \\
\hline & Within Groups & 25.697 & 93 & .276 & & \\
\hline & Total & 26.129 & 97 & & & \\
\hline \multirow{3}{*}{$\begin{array}{l}\text { Culture, } \\
\text { Arts, and } \\
\text { Sports }\end{array}$} & Between Groups & 1.105 & 4 & .276 & .683 & .606 \\
\hline & Within Groups & 37.609 & 93 & .404 & & \\
\hline & Total & 38.714 & 97 & & & \\
\hline \multirow[t]{3}{*}{ Education } & Between Groups & 3.262 & 4 & .815 & 2.130 & .083 \\
\hline & Within Groups & 35.606 & 93 & .383 & & \\
\hline & Total & 38.867 & 97 & & & \\
\hline \multirow{3}{*}{$\begin{array}{l}\text { Volunteer } \\
\text { Awareness }\end{array}$} & Between Groups & 1.568 & 4 & .392 & 1.690 & .159 \\
\hline & Within Groups & 21.573 & 93 & .232 & & \\
\hline & Total & 23.141 & 97 & & & \\
\hline
\end{tabular}

Overall through the ANOVA test, there was no significant difference in volunteer awareness according to occupation. Based on the table above, the study findings revealed an overall volunteer awareness factor $(F=1.690$, sig. $=0.159)$. In terms of education $(F=2.130$, sig. $=$ $0.083)$ culture, arts and sports $(F=0.683$, sig. $=0.606)$, community and social services $(F=$ 0.391 , sig. $=0.814)$ and religious activities $(F=2.280$, sig. $=0.067)$, where the value of sig. $p>$ 0.05 .

All dimensions show that there is no significant difference in volunteer awareness according to the occupation. Based on the total variance between the religious and educational groups exceeds the total variance within the group. The result shows there is a difference in scores for the dimension of the group, and there is no difference in the dimension of culture, arts, and sports as well as community involvement.

Based on the above results, this study found no difference between occupation in terms of volunteer awareness. All fields must know the importance of volunteerism.

Based on the ANOVA analysis, findings show that the tables of one way ANOVA volunteer awareness by race (Table 5). 
INTERNATIONAL JOURNAL OF ACADEMIC RESEARCH IN BUSINESS AND SOCIAL SCIENCES Vol. 10, No. 11, 2020, E-ISSN: 2222-6990 @ 2020 HRMARS

\begin{tabular}{|c|c|c|c|c|c|c|}
\hline \multicolumn{7}{|c|}{ Table 5: One Way ANOVA Volunteer Awareness by Race } \\
\hline & & $\begin{array}{l}\text { Sum of } \\
\text { Squares }\end{array}$ & df & $\begin{array}{l}\text { Mean } \\
\text { Square }\end{array}$ & $\mathrm{F}$ & Sig. \\
\hline \multirow[t]{3}{*}{$\begin{array}{l}\text { Religious } \\
\text { Activities }\end{array}$} & $\begin{array}{l}\text { Between } \\
\text { Groups }\end{array}$ & .388 & 3 & .129 & .491 & .690 \\
\hline & Within Groups & 24.759 & 94 & .263 & & \\
\hline & Total & 25.146 & 97 & & & \\
\hline \multirow{3}{*}{$\begin{array}{l}\text { Community } \\
\text { and Social } \\
\text { Services }\end{array}$} & $\begin{array}{l}\text { Between } \\
\text { Groups }\end{array}$ & .402 & 3 & .134 & .490 & .690 \\
\hline & Within Groups & 25.727 & 94 & .274 & & \\
\hline & Total & 26.129 & 97 & & & \\
\hline \multirow{3}{*}{$\begin{array}{l}\text { Culture, } \\
\text { Arts, and } \\
\text { Sports }\end{array}$} & $\begin{array}{l}\text { Between } \\
\text { Groups }\end{array}$ & .450 & 3 & .150 & .368 & .776 \\
\hline & Within Groups & 38.264 & 94 & .407 & & \\
\hline & Total & 38.714 & 97 & & & \\
\hline \multirow[t]{3}{*}{ Education } & $\begin{array}{l}\text { Between } \\
\text { Groups }\end{array}$ & .932 & 3 & .311 & .770 & .514 \\
\hline & Within Groups & 37.935 & 94 & .404 & & \\
\hline & Total & 38.867 & 97 & & & \\
\hline \multirow[t]{3}{*}{$\begin{array}{l}\text { Volunteer } \\
\text { Awareness }\end{array}$} & $\begin{array}{l}\text { Between } \\
\text { Groups }\end{array}$ & .027 & 3 & .009 & .036 & .991 \\
\hline & Within Groups & 23.114 & 94 & .246 & & \\
\hline & Total & 23.141 & 97 & & & \\
\hline
\end{tabular}

Overall through the ANOVA test, there was no significant difference in volunteer awareness by race. Based on the table above, the study findings revealed an overall volunteer awareness factor $(F=0.036$, sig. $=0.991)$. In terms of education $(F=0.770$, sig. $=0.514)$ culture, arts and sports $(F=0.368$, sig. $=0.776)$, community and social services $(F=0.490$, sig. $=0.690)$ and religious activities $(F=0.491$, sig. $=0.690)$, where the value of sig. $p>0.05$.

All dimensions indicate that there is no significant difference in volunteer awareness according to race. The total variance within the groups exceeds the total variance between the group. This means there is no difference in all the dimensions.

Based on the above results, this study found a no different level of volunteer awareness by race. It is important so that the community is united in helping those in need regardless of race.

Based on the ANOVA analysis, findings show that the tables of One Way ANOVA volunteer awareness by state (table 6). 
INTERNATIONAL JOURNAL OF ACADEMIC RESEARCH IN BUSINESS AND SOCIAL SCIENCES Vol. 10, No. 11, 2020, E-ISSN: 2222-6990 @ 2020 HRMARS

\begin{tabular}{|c|c|c|c|c|c|c|}
\hline \multicolumn{7}{|c|}{ Table 6: One Way ANOVA Volunteer Awareness by State } \\
\hline & & $\begin{array}{l}\text { Sum of } \\
\text { Squares }\end{array}$ & df & $\begin{array}{l}\text { Mean } \\
\text { Square }\end{array}$ & $\mathrm{F}$ & Sig. \\
\hline \multirow{3}{*}{$\begin{array}{l}\text { Religious } \\
\text { Activities }\end{array}$} & Between Groups & .499 & 4 & .125 & .470 & .757 \\
\hline & Within Groups & 24.648 & 93 & .265 & & \\
\hline & Total & 25.146 & 97 & & & \\
\hline \multirow{3}{*}{$\begin{array}{l}\text { Community } \\
\text { and Social } \\
\text { Services }\end{array}$} & Between Groups & .360 & 4 & .090 & .325 & .861 \\
\hline & Within Groups & 25.769 & 93 & .277 & & \\
\hline & Total & 26.129 & 97 & & & \\
\hline \multirow{3}{*}{$\begin{array}{l}\text { Culture, } \\
\text { Arts, and } \\
\text { Sports }\end{array}$} & Between Groups & 2.379 & 4 & .595 & 1.522 & .202 \\
\hline & Within Groups & 36.335 & 93 & .391 & & \\
\hline & Total & 38.714 & 97 & & & \\
\hline \multirow[t]{3}{*}{ Education } & Between Groups & .813 & 4 & .203 & .497 & .738 \\
\hline & Within Groups & 38.054 & 93 & .409 & & \\
\hline & Total & 38.867 & 97 & & & \\
\hline \multirow{3}{*}{$\begin{array}{l}\text { Volunteer } \\
\text { Awareness }\end{array}$} & Between Groups & .618 & 4 & .154 & .638 & .637 \\
\hline & Within Groups & 22.523 & 93 & .242 & & \\
\hline & Total & 23.141 & 97 & & & \\
\hline
\end{tabular}

Overall through the ANOVA test, there was no significant difference in volunteer awareness by state. Based on the table above, the study findings revealed an overall volunteer awareness factor $(F=0.638$, sig. $=0.637)$. In terms of education $(F=0.497$, sig. $=0.738)$ culture, arts and sports $(F=1.152$, sig. $=0.202)$, community and social services $(F=0.325$, sig. $=0.861)$ and religious activities $(F=0.470$, sig. $=0.757)$, where the value of sig. $p>0.05$.

All dimensions indicate that there is no significant difference in volunteer awareness by the state. The total variance between the culture, arts, and sports groups exceeded the group's total variance. It means that there is a difference in scores for the group's dimension, and there is no difference in the dimension of education, community, social services, and religious activities.

This study found no different level of volunteer awareness in the state aspects based on the above results. It is essential in producing a plural Malaysian society regardless of state background.

\section{Conclusion}

In conclusion, this social media representation is significant as a tool for volunteer awareness in youth in Malaysia. It is because the young generation is the strength of society. Therefore, to strengthen the spirit of volunteerism in the youth, everyone should play a role. For example, the individual in the community itself needs to show a good and responsible attitude. The government also plays a key role in broadcasting programs and benefits to volunteers on social media. Thus, the community's soul is educated to sympathy and kindness and produce a harmonious, caring, and loving society in realizing society's sustainable development.

Volunteer organizations can use the knowledge gained from this study to inform their social networking strategy to reach out to volunteers through the tools that volunteers want. Policymakers and stakeholders need to realize that volunteers' awareness by demographics 
is simply one aspect of understanding volunteers' motivation. If used appropriately and consistently, volunteer demographic information may provide direction for planning, organizing, and more importantly, providing the spirit of volunteerism among the younger generation, since that generation will determine the success or backwardness of a country. For further study, the research elements can be expanded to other influential factors such as the study conducted by Tiung et al. (2018) on propaganda and disinformation. This is evidenced by the spread of fake news that can affect the community, especially when the country is experiencing the pandemic COVID 19 (Muhamad, 2020). In the future, elements can be varied to produce better studies.

\section{Acknowledgment}

The authors acknowledge to Faculty of Applied Social Sciences, Sultan Zainal Abidin University, to support this research.

\section{Corresponding Author}

Aziz Amin

Faculty of Applied Social Sciences,

Universiti Sultan Zainal Abidin, Malaysia

Email: wanazizmn@unisza.edu.my

\section{References}

Amin, A., Zolkifeli, Z., \& Hassan, M. S. N. A. (2019). Descriptive research of social capital among low income group in urban areas in east coast of peninsular Malaysia. International Journal of Recent Technology and Engineering, 8(3), 267-269.

Bahari, A. (2010). Permasalahan sosial dalam kalangan pelajar: Keperluan kepada kerja sosial dalam pendidikan. In Prosiding Seminar Kerja Sosial dalam Pendidikan. 10 - $11 \mathrm{Mei}$ 2010, Sintok, Universiti Utara Malaysia.

Batson, C. D., Ahmad, N., \& Tsang, J.-A. (2002). Four motives for community involvement. Journal of Social Issues, 58(3), 429-445.

Brennan, M. A., Barnett, R. V., \& Lesmeister, M. K. (2007). Enhancing local capacity and youth involvement in the community development process. Community Development Journal, 38(4), 13-27.

Delgado, M. (2002). New Frontiers for Youth Development in the Twenty-First Century: Revitalizing and Broadening Youth Development. New York: Columbia University Press. doi:10.7312/delg12280

Falina, H., Mahmud, W. A. W., \& Mahbob, M. H. (2016). The role of media as a social awareness tool among the disabled in Malaysia. Jurnal Komunikasi: Malaysian Journal of Communication, 32(2), 471-488.

Ishak, M. S., Ismail, A., Mat, B., Kassim, A., Mamat, S., \& Talib, N. (2016). Belia dan penggunaan media sosial. Malaysian Journal of Youth Studies, 15(9), 149-165.

Muhamad, H. (2020). Berita palsu "lebih cepat" tersebar berbanding virus COVID-19 -Dr Noor Hisham. Retrieved from https://www.astroawani.com/berita-malaysia/berita-palsulebih-cepat-tersebar-berbanding-virus-covid19-dr-noor-hisham-246713.

Nadarajaw, T. (2014). Teen Volunteers. Retrieved from http://www.myhealth.gov.my/en/teen-volunteers/

Ribaric, H. M., Nimac, K. R., \& Nad, M. (2013). Volunteering and competitiveness on the labour market in times of crisis: Student's attitudes. In 2nd International Scientific 
Conference Tourism in South East Europe (pp. 217-229).

Shah, J. A., Suandi, T., Hamzah, S. R., \& Ismail, I. A. (2015). Why youths choose to become volunteers: from the perspective of belief. Athens Journal of Social Sciences, 2(1), 5164.

Tiung, L. K., Idris, R. Z., \& Idris, R. (2018). Propaganda dan disinformasi: Politik persepsi dalam pilihan raya umum ke-14 (pru-14) Malaysia. Jurnal Kinabalu, 171-198.

Wilson, J. (2000). Volunteering. Annual Review of Sociology 26(1), 215-240.

Zolkifeli, Z., \& Amin, A. (2018). The effects of social capital and mental health on quality of life among low income group in urban areas in east coast of peninsula Malaysia. International Journal of Civil Engineering and Technology, 9(8), 904-909.

Zolkifeli, Z., \& Amin, A. (2019). Mental health and social capital among B40 groups in east coast of Peninsular Malaysia. Indian Journal of Public Health Research \& Development, 10(10), 808-812. 